UDC 94(495)+94(560)“13”+82-94

Submitted: 25.06 .2018

LBC T3(0)4-93

Accepted: 07.09.2018

\title{
THE FATE OF THE LOST LANDS AS VIEWED BY BYZANTINE EMPEROR MANUEL II PALAIOLOGOS ${ }^{1}$
}

\author{
Tatiana V. Kushch \\ Ural Federal University, Ekaterinburg, Russian Federation
}

\begin{abstract}
Introduction. In the Late Byzantine Period, the predominant trend was the reduction of possessions of the emperors of the Palaiologoi dynasty. The main reason of the Empire's territorial decay was the Ottoman conquests.

Methods. The methods of historical-anthropological and imagological research allow us to trace the value of ideological constructions that formed the notions of the place of the Romaioi state in the Oikoumene under the conditions of territorial reduction in the current Byzantine mind, and the degree of historical realities' influence on the Romaioi's perception of their own space.

Analysis. The author of this paper has put the following questions: how did the Byzantines perceive their territorial losses? how did the view the lost lands? how did they understand the fate of the people that found themselves under the conquerors? Searching for answers to these questions, the author uses the history of Byzantine Emperor Manuel II Palaiologos' visit to the lands of Anatolia. As sultan's vassal, in 1390-1391 Manuel II participated in the Ottoman raids to Asia Minor. This paper analyses the description of the lost territories in the Manuel II's letters.

Results. In the view of Manuel II, the barbarian conquest of Byzantine possessions started their "decivilization": the destruction of urban and rural settlements, depopulation, changes of the ethnic structure, decline of the living standards, neglecting Greek culture and language, and the erasing of the Romaion past. The fate of the lands conquered by the Ottomans was viewed as sorrowful, especially in comparison with their former flourishing and prosperity under the Romaioi. The disappearance of Greek place-names in the Asia Minor and the destruction on the Greek world order were the mostly visible results of the loss of Romaion control over these territories. Although barbaric names of former lands and ruined traces of the Byzantine presence changed the civilization landscape of the periphery of the former Romaion orbis terrarum, they did not expelled them from the "imagined" Greek world.
\end{abstract}

Key words: Late Byzantium, Ottoman conquests, Manuel II Palaiologos, loss of lands, fate of the conquered population.

Citation. Kushch T.V. The Fate of the Lost Lands as Viewed by Byzantine Emperor Manuel II Palaiologos. Vestnik Volgogradskogo gosudarstvennogo universiteta. Seriya 4, Istoriya. Regionovedenie. Mezhdunarodnye otnosheniya [Science Journal of Volgograd State University. History. Area Studies. International Relations], 2018, vol. 23, no. 5, pp. 147-156. (in Russian). DOI: https://doi.org/10.15688/jvolsu4.2018.5.13

УДК 94(495)+94(560)“13”+82-94

ББК ТЗ(0)4-93

Дата поступления статьи: 25.06.2018

Дата принятия статьи: 07.09.2018

\section{СУДЬБА УТРАЧЕННЫХ ТЕРРИТОРИЙ: ВЗГЛЯД ВИЗАНТИЙСКОГО ИМПЕРАТОРА МАНУИЛА ІІ ПАЛЕОЛОГА ${ }^{1}$}

\section{Татьяна Викторовна Кущ}

Уральский федеральный университет, г. Екатеринбург, Российская Федерация

Аннотация. В поздневизантийское время доминирующей тенденцией стало сокращение владений императоров Палеологовского дома. Главной причиной территориального угасания империи были османские завоевания. Методы историко-антропологических и имагологических исследований позволяют проследить, 


\section{СУДЬБА МАЛОЙ АЗИИ В ВОСПРИЯТИИ ВИЗАНТИЙЦЕВ}

насколько актуальными оставались в византийском сознании идеологические конструкты, формировавшие представления о месте ромейского государства в ойкумене, в условиях территориального сокращения, и в какой степени исторические реалии влияли на восприятие ромеями собственного пространства. Автор статьи ставит следующие вопросы: как же воспринимали византийцы территориальные потери; как они относились к утраченным территориям; какой они представляли судьбу населения, оказавшегося под властью завоевателей? В поиске ответов на эти вопросы автор статьи обращается к сюжету о посещении византийским императором Мануилом II Палеологом анатолийских земель. Как вассал султана Мануил II в 1390-1391 гг. участвовал в османских походах в Малую Азию. Описания утраченных территорий, содержащиеся в письмах Мануила II, и стали предметом анализа в настоящей статье. С завоеванием варварами византийских владений происходила, на взгляд Мануила II, «де-цивилизация» территории: разрушение городских и сельских поселений, депопуляция, смена этнического состава населения, падение уровня их жизни, забвение греческой культуры и языка, стирание ромейского прошлого. Судьба покоренных турками земель представляется печальной, особенно в сравнении с их прежним процветанием и благополучием при ромеях. Исчезновение греческой топонимии в Малой Азии, разрушение греческого миропорядка - наиболее очевидные результаты потери ромейского контроля над этими территориями. «Варварские» названия прежних территорий и руинированные следы византийского присутствия изменили цивилизационный ландшафт периферии бывшего ромейского orbis terrarum, но не исключили их из «воображаемого» греческого мира.

Ключевые слова: Поздняя Византия, турецкие завоевания, Мануил II Палеолог, утрата территорий, судьба завоеванного населения.

Цитирование. Кущ Т. В. Судьба утраченных территорий: взгляд византийского императора Мануила II Палеолога // Вестник Волгоградского государственного университета. Серия 4, История. Регионоведение. Международные отношения. - 2018. - Т. 23, № 5. - C. 147-156. - DOI: https://doi.org/10.15688/jvolsu4.2018.5.13

Введение. «Свое пространство»в Средневековье, да собственно и в другие эпохи, имеет не только географические, но и ментальные границы. Освоение физического пространства неразрывно связано с его политическим, экономическим, религиозным, интеллектуальным, символическим присвоением. Свою землю населяют соплеменники (сограждане/соотечественники), которые говорят на одном языке, имеют общую историю, исповедуют единую религию, ведут схожий образ жизни, принадлежат к общей культуре. Окультуривание географического пространства было основой для создания и поддержания политической общности живущих на одной территории людей. Утрата территорий означала не только потерю собственных владений, но и культурного пространства в более широком смысле.

Византийские представления о собственных территориях нашли выражение в стройной политической теории, опиравшейся на римскую доктрину orbis terrarum и христианскую идею богоизбранности. Согласно византийской традиции земли, находящиеся под управлением василевса ромеев, отождествлялись с пределами цивилизованного мира - ойкумены [16, р. 56]. Миссией императора было защищать богохранимое государство [4, p. 91;
17, S. 43-44]. Даже очевидное противоречие между доминировавшей на протяжении столетий идеей ойкуменизма и меняющимися историческими реалиями не могли разрушить представления византийцев об исключительном месте их империи на карте тогдашнего мира [5, р. 55].

Границы Византийского государства за его тысячелетнюю историю постоянно менялись: владения империи то прирастали новыми приобретениями, то таяли под натиском завоевателей. В поздневизантийское время доминирующей тенденцией становится сокращение территорий, находившихся под властью императоров Палеологовского дома. К XIV в. от былого могущества Ромейской державы остались лишь воспоминания. Империя уже давно утратила единство - ее территории оказались изолированы друг от друга. Происходила, используя выражение А. Лайю, «фрагментация византийского пространства» [11, p. 42]. Главной причиной катастрофического угасания империи во второй половине XIV в. были османские завоевания. Вошедшие во вкус и жадные до новых приобретений турки вытеснили ромеев сначала с их исконных малоазийских земель, а с середины XIV в. приступили к планомерному захвату их балканских владений. К концу столетия империя ро- 
меев ограничивалась Константинополем, Мореей и несколькими эгейскими островами. Теперь о византийский берег били волны безбрежного «турецкого моря», разлившегося на огромных просторах прежней греческой ойкумены и угрожавшего затопить последние островки византийской цивилизации. Как же воспринимали византийцы территориальные потери, вследствие которых греческий orbis terrarum так стремительно сокращался? Как они относились к утраченным территориям? Что сталось с землями, перешедшими под власть завоевателей? Какой виделась ромеям дальнейшая судьба территорий, ушедших из-под их контроля? Ответив на эти вопросы, можно оценить, что понимали византийцы под «своим пространством» и как они маркировали собственные земли.

Методы. Опираясь на методы историко-антропологических и имагологических исследований, рассмотрим, каким виделось византийцам положение собственных территорий, волею судьбы оказавшихся под властью турок. Подобный подход позволит проследить, насколько актуальными оставались в византийском сознании идеологические конструкты, ранее формировавшие представления о месте ромейского государства в ойкумене, в условиях катастрофического территориального сокращения, и в какой степени исторические реалии, явно контрастировавшие с идеей собственного превосходства, влияли на восприятие ромеями собственного пространства.

Изучение истории турецких завоеваний, имеющее давнюю и устойчивую историографическую традицию, продолжает находиться в центре внимания современных исследователей. Обращаясь к позднему периоду византийской истории, ученые концентрируют свое внимание не только на событийной канве и перипетиях политического и религиозного взаимодействия ромеев и османов $[6 ; 9 ; 15 ; 22$; $25 ; 26]$, но и активно занимаются изучением имагологических аспектов восприятия византийцами турок и турецкой угрозы $[1 ; 2 ; 14 ; 18]$. Углубляя этот подход, мы и остановимся на сформулированной выше проблеме.

Анализ. То, что для империи ромеев угроза, исходившая от османов, представляла реальную опасность, без устали твердят все византийские авторы, с тревогой наблюдав- шие за растущей мощью турецкого государства. На протяжении всего столетия тема турецкого завоевания была лейтмотивом и политических трактатов, и официальной риторики, и религиозной полемики, и частной переписки. Действительно, проблема турецкой агрессии была не только предметом высокоинтеллектуальной рефлексии и отстраненных размышлений на злободневную тему, но и поводом для личных переживаний, вызванных опытом непосредственных контактов с противником. Именно такой опыт соприкосновения с реальностью особенно интересен для исследователя. Мы, в частности, располагаем несколькими уникальными сообщениями императора Мануила II Палеолога (13911425) о посещении им земель, уже давно и плотно находившихся под властью восточных соседей. Причина его вынужденного пребывания на отторгнутых когда-то византийских территориях крылась в изменившемся к последней трети XIV в. внешнеполитическом положении империи, доставшейся ему в наследство.

С 1371 г. Византия находилась в вассальной зависимости от турецкого правителя. Император, помимо уплаты дани, должен был являться в ставку султана, согласовывать с ним свои внешнеполитические планы, участвовать в его военных кампаниях. Кроме того, вся внутриполитическая ситуация Византии по сути контролировалась и координировалась турками. Правитель османов выступал третейским судьей в спорах между представителями дома Палеологов, оспаривающими престол, примирял противоборствующие стороны, поддерживал ту или иную из них в периоды обострения династических конфликтов. Не случайно во время конфронтации императора Иоанна V Палеолога с собственными сыновьями (сперва с Андроником IV, позже с Мануилом II) последнее слово оставалось за султаном, который, играя на внутренних противоречиях, определял судьбу византийского престола. Эта унизительная зависимость империи от османского двора очень точно передана Димитрием Кидонисом в 1391 г. в письме деспоту Мореи Феодору I Палеологу: «Продолжает свирепствовать старое зло, которое причинило общее разорение. Я имею в виду раздоры между императора- 


\section{СУДЬБА МАЛОЙ АЗИИ В ВОСПРИЯТИИ ВИЗАНТИЙЦЕВ}

ми из-за призрака власти. Ради нее они вынуждены служить варвару (султану. - T. K.); это единственный путь, дающий возможность выжить. Всякий понимает, что кому из двоих варвар окажет поддержку, тот и возобладает. Поэтому императоры по необходимости превращаются в его рабов на глазах у граждан и следуют его требованиям» [8, ер. 442. 41-47].

Империя, величие которой составляло предмет гордости для всех поколений ромеев, оказалась раздавленной и униженной не только потому, что лишилась практически всех своих владений, но и потому, что попала в зависимость от тех, кого византийцы всегда презрительно называли варварами. Ощущение трагедии, которую переживала Византия, и осознание беспомощности власти, вынужденной мириться с унижением, не покидали и Димитрия Кидониса, писавшего в 1391 г. в письме Иоанну Ласкарису Калоферу следующие строки: «Я, оставшись здесь (в столице. - T. К.), стал свидетелем несчастий, выпавших на долю моего отечества, ибо мне приходится видеть то, как прославленная много раз держава ромеев растоптана в прах варварами, которые не раз желали ее поработить; то, как все, что прежде ей принадлежало, уступлено им; все, некогда завоеванное благодаря ее превосходству в силах, ныне потеряно. Осталась от нее, подобно голове, отделенной от туловища, только одна столица, которая ныне со своими правителями пышно исполняет рабскую службу» [8, ер. 436. 18 24]. Горечь территориальных утрат усугубляется, по мысли Кидониса, осознанием того, что «прославленная много раз держава ромеев» оказалась в рабской зависимости от султана, а правитель ромеев позорно следует воле своего главного врага. Но в этих горьких строках, оплакивающих судьбу ромеев, отраженным светом мерцает и извечная вера в величие собственной империи, пусть и попранной в данный момент варваром. Кидонис даже в тяжкие минуты испытаний, выпавших на долю его соотечественников, сохраняет убежденность в исключительном положении империи, которая всегда превосходила своих соседей в силе и могуществе, а потому достойна славы и восхвалений. Однако текущая ситуация была такова, что император, словно раб, покорно повиновался султану.
Именно как «рабскую службу» воспринимал Мануил II Палеолог обязанность участвовать в военных походах турок. С приходом к власти султана Баязида I (1389-1402) османы стали активно действовать в Малой Азии, пытаясь установить контроль над регионом и подчинить себе многочисленные бейлики. К этим военным операциям и привлекались военные силы ромеев, которые, в силу своего вассального положения, вынуждены были по первому требованию являться на зов султана [21, p. 292].

Осенью 1390 г. Баязид I призвал ромейские войска под командованием Мануила II, тогда еще соправителя своего отца-императора, и его непокорного племянника Иоанна VII присоединиться к походу против западно-анатолийских эмиров, вышедших изпод подчинения османов [21, p. 331]. В период этой кампании Мануилу II даже пришлось лично участвовать во взятии христианского города Филадельфии, последнего византийского оплота в этом регионе [7, p. 79]. В июне 1391 г. Мануил II, только что унаследовавший византийский престол, вновь прибыл вместе со своим отрядом в расположение турецкого войска, завершавшего разгром эмирата Кастамону [7, p. 86; 20, p. 40; 27, p. 472]. Затем коалиционные силы предприняли поход против Кади Бурханеддина Ахмеда, правителя Сиваса, с которым уже давно конфликтовали османы [27, p. 473]. Так, в течение осени 1391 г. византийский отряд Мануила успел повоевать в составе войск Баязида I в Пафлагонии и на Понте в районах Синопа, Амасии и Амиса. Мануил II прекрасно осознавал последствия своей вынужденной коалиции с турками, но лишь обреченно констатировал: «Мы выбираем между одним страхом и другим, между одной опасностью и другой, между одним бременем и другим, между меньшими (бедами. $-T$. K.) и большими - я сравниваю то, чему мы подвергаемся сейчас в коалиции с персами, с тем, чего можно было бы ожидать от них, если бы мы не сражались в их рядах» [24, ер. 14. 25-28]. Военное взаимодействие с османами, которых Мануил II на античный лад называет персами [3, с. 82 ; 10, p. 76-77; 13, S. 359], было вынужденной мерой, выбором между двух зол, но и оно таило в себе, по убеждению автора, цивилиза- 
ционную угрозу. Вынужденное участие в военных кампаниях своих врагов было для императора тяжким испытанием: «Для нас особенно невыносима обязанность сражаться вместе с теми и за тех, чье усиление уменьшит наши собственные силы» [24, ер. 19. 8-10].

Впечатления от этого малоазийского похода и нашли отражение в письмах (своего рода путевых записках) Мануила II, которые он с нарочными отправлял друзьям в столицу. Ценность этих сообщений кроется в том, что они зафиксировали по свежим следам все то, что пришлось пережить и воочию увидеть императору.

Дорога к цели военной экспедиции пролегала через малоазийские земли, давно утраченные византийцами. Мануил II в письме Димитрию Кидонису писал следующее: «Я направился с ромеями из своей земли в земли скифов, чтобы вести войну со скифами и командовать войсками для наших врагов» [24, ер. 14. 10-12]. Он четко разграничивает нашу страну и «земли скифов», под которыми он подразумевает монгольские владения. Используя антикизирующее название «скифы», он еще больше дистанцирует собственные владения от тех территорий, которые заселены иноплеменниками. И все же эти «скифские» земли, хоть и воспринимаются им как чужие территории, в его исторической памяти связаны с их ромейским прошлым.

Так, во время военного перехода войско оказалось в Богом забытой местности, которая произвела на императора сильное впечатление. Мануил в одном из своих писем дал развернутое и эмоционально напряженное описание этого места: «Маленькая равнина, на которой мы теперь стоим, конечно, носила какое-то имя, когда имела счастье быть населенной и управляемой ромеями. Но теперь, когда я спрашиваю, каким оно было, я бы мог с тем же успехом спрашивать о волчьих крыльях из пословицы, ибо здесь нет абсолютно никого, кто бы мне рассказал об этом. Конечно, ты можешь увидеть здесь много городов, но им недостает того, что составляет истинное великолепие города и без чего они не могут быть по-настоящему названы городами, то есть - человеческих существ. Большинство этих городов сейчас лежат в руинах жалкое зрелище для тех, чьи предки когда-то владели ими. От городов не сохранилось даже имен, так давно они были разрушены. На самом деле, когда я вопрошал о названиях этих городов, люди отвечали мне: «Мы разрушили эти города, а время стерло их имена». Меня охватила печаль, хотя я нес ее в молчании, так как мог еще контролировать себя. Но, можешь представить себе, как я, когда ктонибудь, не зная о древнем названии города, называл его варварским или каким-то странным на слух именем, громко плакал и едва мог скрыть свою печаль, хотя стремился себя сдерживать» [24, ер. 16. 22-36]. Местность, которую так подробно описал Мануил, трудно идентифицировать, но, очевидно, она находилась где-то по дороге из Синопа в направлении Амиса (Самсуна) [27, р. 477].

Приведенный выше фрагмент письма содержит несколько ключевых характеристик, маркирующих «ромейское прошлое» той территории, в которой император «узнал» прежние владения своих далеких предков. Первое, что бросается ему в глаза, это «безымянность» той местности, которую он воспринимает как исторически ромейскую. Мануил II упоминает, что маленькая равнина, через которую пролегал его путь, определенно имела когда-то греческое название, как и города, которые, как он отмечает, ныне лежат в руинах. Действительно, топонимы всегда отражали этническую принадлежность населения, здесь обитавшего. Включенность географических объектов в «свое» политическое пространство происходила в том числе и за счет их переименования. Заселяя земли, новое население всегда присваивало им собственные названия, придавая им новые культурные смыслы, «столбило» их как свои владения. Греческая топонимия выступала лингвистическим маркером территории, являвшейся частью империи. Исконная принадлежность греческой ойкумене областей, которые описывает император, подчеркивается древностью их названий - Мануил II говорит о «древнем названии города», которое уже никто не помнит («время стерло их имена»). Забвение прежних греческих названий географических объектов свидетельствовало не только об их окончательном выпадении из сферы византийского политического влияния, но и смене населения, у которого уже атрофировалась «топоними- 


\section{СУДЬБА МАЛОЙ АЗИИ В ВОСПРИЯТИИ ВИЗАНТИЙЦЕВ}

ческая» память о месте их обитания. Факт утраты политического контроля над местностью и смены этнолингвистического состава населения подтверждался и переименованием географических объектов. Вот почему Мануила II повергает в уныние не только забвение прежних, родных для ромейского слуха названий, но и появление новых, звучащих чуждо («по-варварски»), топонимов. Отсутствие греческой топонимики в местах, которые когда-то составляли часть собственной ойкумены, полностью дезориентирует Мануила: «Признаться, я даже не могу тебе точно назвать, в какой части света мы находимся, ибо как ктолибо может назвать места, не имеющие больше названия?» [24, ер. 16. 37-39].

Обращает на себя внимание еще один момент в приведенной цитате. Говоря о безвестной равнине, Мануил II добавляет важную характеристику ее прошлого - в прежние времена она «имела счастье быть населенной и управляемой ромеями». Василевс, демонстрирующий убежденность в том, что принадлежность к «греческому миру» обеспечивала благополучие и процветание жителям любой, даже очень отдаленной области, очевидно следует традиционным представлениям о величии империи, гарантирующей своим согражданам порядок и стабильность. В рамках византийского политического дискурса любой народ был счастлив населять ромейскую ойкумену. Очевидно, Мануил II оставался в плену прежних идеологических штампов, несмотря на суровую реальность, с которой ему приходилось сталкиваться.

Лейттемой рассуждений о судьбе покоренных земель остается их бедственное положение. Завоевание византийских территорий варварами влекло за собой их упадок и разруху. Варвары всегда воспринимались византийским сознанием как носители деструктивного начала, как сила, повергающая поко-

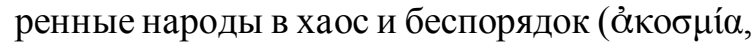
$\dot{\alpha} \tau \alpha \xi \dot{\xi} \alpha)$, в то время как империя всегда стремилась создавать и поддерживать универсальный порядок ( $\tau \dot{\alpha} \xi 1 \varsigma)$ [23, p. 197]. Это устойчивый идеологический конструкт дает о себе знать и при описании Мануилом II поселений, встреченных во время марша. Города лежат в руинах - часто повторяющийся мотив в характеристике утраченной территории. Имен- но в такой тональности он подробно описывает увиденный им древний город Помпеополис, некогда богатый и процветающий, ныне же разрушенный и разоренный: «Ты слышал о городе Помпея, красивом, удивительном, огромном, вернее, он таким был, так как сейчас ты его едва сможешь различить среди руин; он расположен на берегах реки, которую пересекает каменный мост, украшен колоннадами, удивительными своими размерами, красотой и искусной конструкцией. В самом деле, этот город и эти величественные останки объясняют, почему ромеи назвали его основателя “Великим"» [24, ер. 16. 42-47]. Одним словом, турки, в представлении Мануила, только и делали на покоренных землях, что «уничтожали города и народы» [24, ep. 17. 18], в то время как византийцы созидали и заботились об устройстве собственных территорий.

Еще одним результатом потери византийского контроля над территорией Мануилу II видится сокращение населения, которое составляет, по его словам, «истинное великолепие города»: прежние обитатели покинули эти области, а те немногочисленные уцелевшие жители испытывали лишения и подвергались постоянной опасности. Он красочно описывает их жалкое существование: «Оно (место. - T. К.) оставлено жителями, которые укрылись в расселинах скал, в лесах и в горах, пытаясь спастись от смерти, от которой, однако, нет спасения, от жесточайшей и бесчеловечной смерти без какой-либо видимости справедливости. Ибо всякий раз открытые (для жалобы. - T. К.) уста были немедленно затворены мечом. Никого не щадили: ни малых детей, ни беззащитных женщин. У тех, кто не может спастись бегством в силу преклонного возраста или болезни, нет надежды избежать смертоносного клинка» [24, ер. 16. 7-14]. Бедственное положение населения - еще один знак несчастной доли тех, кому было уготовано судьбой оказаться под властью варваров.

Император, описывая картину упадка утраченной Византией территории, постоянно апеллирует к ее прошлому - к древним названиям мест, к великим предкам, к прежнему процветанию в составе империи. Обращение к славному прошлому только усиливает контраст с нынешним бедственным состоянием земель, некогда принадлежавших его 
предшественникам. Не думаю, что для него это лишь риторический прием. Сознанию византийцев было свойственно подобное восприятие прошлого как золотого времени, служившего последующим поколениям примером для подражания и мерилом оценки их собственного состояния. Одно из писем, отправленных из этого похода, он завершает словами: «Пусть он (Господь. $-T$. K.), добрый и держащий все в своих руках, избавит нас от насущного зла и приведет как можно скорее к процветанию наших предков» [24, ер. 19. 39-42]. Да, прежнее великолепие империи осталось далеко позади, но оно не прошло бесследно и, более того, может по воли Божьей стать когда-то настоящим.

Выводы. Итак, с завоеванием варварами византийских владений происходила, на взгляд Мануила II, «де-цивилизация» территории: разрушение городских и сельских поселений, депопуляция, смена этнического состава населения, падение уровня их жизни, забвение греческой культуры и языка, стирание ромейского прошлого. Судьба покоренных османами земель представляется незавидной и печальной, особенно в сравнении с царившим здесь когда-то процветанием и благополучием. Зеркальным образом можно определить и маркеры, которыми византийское сознание помечает собственные земли - они мудро управляются византийской властью, их население сохраняет свою религиозную, языковую и культурную идентичность, благоденствует и испытывает гордость за свою принадлежность к ромеям. Подобное противопоставление собственных территорий и уже утраченных земель только укрепляют убежденность византийцев в собственном превосходстве над остальными народами.

Сообщения Мануила II - эти свидетельства «от первого лица» - представляют для нас особую ценность, ведь они запечатлели личный опыт столкновения с новым геополитическим порядком. Мануил II, воочию увидев земли, давно уже не принадлежавшие империи, описывает результаты политических и культурных перемен, произошедших на протяжении последних столетий. Вымывание греческой топонимии в Малой Азии, утрата исконных названий, разрушение греческого миропорядка - наиболее оче- видные результаты «выпадения» территории из прежнего культурного пространства. «Варварские» названия прежних территорий и руинированные следы византийского присутствия изменили цивилизационный ландшафт периферии бывшего ромейского orbis terrarum, но не исключили их из «воображаемого» греческого мира.

С другой стороны, тот же Мануил II, видевший разорение и упадок бывших византийских владений, продолжал придерживаться идеи превосходства ромеев над остальными народами. В его политической риторике всегда присутствовали слова, подчеркивающие исключительное положение Византии в христианском мире. В «Надгробной речи» на смерть деспота Мореи Феодора I, говоря о Константинополе, он выразил эту идею господства империи над всеми народами следующим образом: «Ибо он (Константинополь. $-T . K$.) - красивейший город среди всех изумительных городов и превосходит их своими несравненными достоинствами, он управляет всеми областями, народами и правителями на земле, побеждая их не столько большим войском и оружием, сколько добродетелью и благоразумием. С тех пор, как Константину вручили в руки скипетр, империя получила человека, который действительно был для всех и предводителем, и распорядителем благодетели. И особенно важно, что его любил Бог за ревностное служение и добродетель так, что с Его божественной помощью и поддержкой он стал основателем этого города» [12, p. 83. 13-19]. И все же василевсу приходилось делать поправки в политической доктрине на реалии своего времени: теперь не военным преимуществом, а идейным превосходством и христианскими добродетелями можно было обосновывать универсалистские амбиции [19, p. 68], не имевшие, однако, под собой уже никаких других оснований.

\section{ПРИМЕЧАНИЕ}

${ }^{1}$ Исследование выполнено при финансовой поддержке РФФИ (проект № 18-09-00091 «Турецкие осады поздневизантийских городов: особенности функционирования городского социума в ситуации межцивилизационного конфликта»). 


\section{СУДЬБА МАЛОЙ АЗИИ В ВОСПРИЯТИИ ВИЗАНТИЙЦЕВ}

\section{СПИСОК ЛИТЕРАТУРЫ}

1. Ангелов, В. Образът на османците във византийската историография от XV век / В. Ангелов // Bulgaria Mediaevalis. -2010. - T. 1. - C. 217-235.

2. Кущ, Т. В. Турки под стенами Константинополя (1422) : Образ врага в восприятии защитников города / Т. В. Кущ // Известия Уральского федерального университета. Серия 2, Гуманитарные науки. 2015. - № 4 (145). - С. 105-115.

3. Шукуров, Р. М. Тюрки в Византии (12041461) / Р. М. Шукуров. - М. : Изд-во Моск. ун-та, 2017. $-631 \mathrm{c}$.

4. Angelov, D. Imperial Ideology and Political Thought in Byzantium, 1204-1330 / D. Angelov. Cambridge : Cambridge Univ. Press, 2007. - 453 p.

5. Angelov, D. "Asia and Europe Commonly Called East and West" Constantinople and Geographical Imagination in Byzantium / D. Angelov // Imperial Geographies in Byzantine and Ottoman Space / ed. by S. Bazzaz, Y. Batsaki, D. Angelov. - Washington : Harvard University Press, 2013. - P. 43-68.

6. Balivet, M. Byzantins et Ottomans : Relations, Interactions, Succession / M. Balivet. - Istanbul : Editions Isis, 1999. - $278 \mathrm{p}$.

7. Barker, J. W. Manuel II Palaeologus (13911425) : A Study in Late Byzantine Statesmanship / J. W. Barker. - New-Brunswick; New-Jersey : Rutgers University Press, 1969. -614 p.

8. Démétrius Cydonès. Correspondance. Vol. 2 / publ. par R.-J. Loenertz. - Città del Vaticano: Biblioteca Apostolica Vaticana, 1960. - 497 p. -(Studi e testi ; 208).

9. Ducellier, A. Chrétiens d'Orient et Islam au Moyen âge : VII ${ }^{\mathrm{e}}-\mathrm{XV}^{\mathrm{e}}$ siècle / A. Ducellier. - Paris : A. Colin, 1996. -492 p.

10. Durak, K. Defining the "Turk" : Mechanisms of Establishing Contemporary Meaning in the Archaizing Language of the Byzantines / K. Durak // Jahrbuch der Österreichischen Byzantinistik. 2009. - Bd. 59. - P. 65-78.

11. Laiou, A. Byzantium and the Neighboring Powers : Small-State Policies and Complexities / A. Laiou // Byzantium : Faith and Power (1261-1557). Perspectives on Late Byzantine Art and Culture / ed. by S. T. Brooks. - New Haven ; L. : Yale University Press, 2006. - P. 42-53.

12. Manuel II Palaeologus. Funeral Oration on His Brother Theodore / Introd., text, transl. and notes by J. Chrysostomides. - Thessalonike : Assoc. for Byzantine Research, 1985. $-310 \mathrm{p}$.

13. Moravcsik, G. Byzantinoturcica. II. Sprachreste der Türkvölker in den byzantinischen Quellen / G. Moravcsik. - Berlin : Akademie Verlag, 1958. - xxv, 376 S.

14. Moustakas, K. Byzantine "Visions" of the Ottoman Empire : Theories of Ottoman Legitimacy by Byzantine Scholars after the Fall of Constantinople / K. Moustakas // Images of the Byzantine World: Visions, Messages and Meanings: Studies Presented to L. Brubaker / ed. by A. Lymberopoulou. - Farnham ; Burlington : Ashgate Publ., 2011. - P. 215-229.

15. Necipoğlu, N. Byzantium between the Ottomans and the Latins. Politics and Society in the Late Empire / N. Necipoğlu. - Cambridge : Cambridge University Press, 2009. $-350 \mathrm{p}$.

16. Obolensky, D. The Principles and Methods of Byzantine Diplomacy / D. Obolensky // Actes du XII ${ }^{\mathrm{e}}$ Congrès international d'études byzantines. T. 1. Beograd : Naučno delo, 1963. - P. 45-61.

17. Ostrogorsky, G. Die byzantinische Staatenhierarchie / G. Ostrogorsky // Seminarium Kondakovianum. - 1936. - T. 8. - S. 41-61.

18. Preiser-Kapeller, J. P. Conversion, Collaboration and Confrontation : Islam in the Register of the Patriarchate of Constantinople ( $14^{\text {th }}$ Century) / J. P. Preiser-Kapeller // International Review of Turkish Studies. - 2011. - Vol. 1, iss. 4. - P. 62-79.

19. Radošević, N. Waiting for the End-the Byzantine Rhetoric of the First Half of the Fifteenth Century / N. Radošević // Зборник радова Византолошког института. - 2006. - Т. 43. - Р. 59-70.

20. Reinert, S. W. Manuel II Palaeologos and His Müderris / S. W. Reinert // The Twilight of Byzantium. Aspects of Cultural and Religious History in the Late Byzantine Empire / by S. Ćutčić, D. Mouriki. - Princeton : Princeton University Press, 1991. - P. 39-51.

21. Reinert, S. W. The Palaiologoi, Yildirim Bāyezīd and Constantinople: June 1389-March 1391 / S. W. Reinert // TO E $\Lambda \Lambda H N I K O N$ : Studies in Honor of Speros Vryonis. Vol. 1 / ed. by J. S. Langdon, S. W. Reinert, J. Allen, Ch. Ioannides. - New Roshelle ; N. Y. : A.D. Caratzas, 1993. - P. 289-366.

22. Spiridonakis, B. G. Grecs, Occidentaux et Turcs de 1054 à 1453 : Quatre siècles d'histoire de relations internationales / B. G. Spiridonakis. - Thessaloniki : Institute for Balkan Studies, 1990. - 291 p.

23. Strano, G. Le rappresentazioni del nemico : Realien e ideologia nella trattatistica militare bizantina / G. Strano // Miscellanea di studi storici. -2009-2010. T. 16. - P. 181-203.

24. The Letters of Manuel II Palaeologus / ed. G. T. Dennis. - Washington : Dumbarton Oaks Center for Byzantine Studies, 1977. - $252 \mathrm{p}$.

25. Vryonis, S. The Decline of Medieval Hellenism in Asia Minor and the Process of Islamization from the Eleventh through the Fifteenth Century / S. Vryonis. - Berkeley ; Los Angeles : California University Press, 1971. - 532 p.

26. Zachariadou, E. Religious Dialogue between Byzantines and Turks during the Ottoman Expansion / E. Zachariadou // Religionsgespräche im Mittelalter 
/ ed. by B. Lewis, F. Niewöhner. - Wiesbaden : Otto Harrassowitz, 1992. - P. 289-304.

27. Zachariadou, E. Manuel II Palaeologos on the Strife between Bayezid I and Kadi Burhan al-din Ahmad / E. Zachariadou // Zachariadou, E. Romania and the Turks (c. 1300 - c. 1500). Pt. IV / E. Zachariadou. -L. : Variorum Reprints, 1985. - P. 471-481.

\section{REFERENCES}

1. Angelov V. Obrazat na osmantsite vav vizantiyskata istoriografiya ot XV vek [The Image of the Ottomans in the $15^{\text {th }}$-Century Byzantine Historiography]. Bulgaria Mediaevalis, 2010, no. 1, pp. 217-235 (in Bulgarian).

2. Kushch T.V. Turki pod stenami Konstantinopolya (1422): Obraz vraga v vospriyatii zashchitnikov goroda [The Turks under the Walls of Constantinople (1422): The Image of the Enemy Viewed by the City's Defenders]. Izvestiya Uralskogo federalnogo universiteta. Seria 2, Gumanitarnye nauki, 2015, no. 4 (145), pp. 105-115 (in Russian).

3. Shukurov R.M. Tyurki v Vizantii (12041461) [The Turks in Byzantium (1204-1461)]. Moscow, MGU Publ., 2017.631 p. (in Russian).

4. Angelov D. Imperial Ideology and Political Thought in Byzantium, 1204-1330. Cambridge, Cambridge University Press, 2007. 453 p.

5. Angelov D. Asia and Europe Commonly Called East and West. Constantinople and Geographical Imagination in Byzantium. Bazzaz S., Batsaki Y., Angelov D., eds. Imperial Geographies in Byzantine and Ottoman Space. Washington, Harvard University Press, 2013, pp. 43-68.

6. Balivet M. Byzantins et Ottomans: relations, interactions, succession. Istanbul, Editions Isis, 1999. $278 \mathrm{p}$.

7. Barker J.W. Manuel II Palaeologus (13911425): A Study in Late Byzantine Statesmanship. New Brunswick; New Jersey, Rutgers University Press, 1969. $614 \mathrm{p}$

8. Loenertz R.-J., ed. Démétrius Cydonès. Correspondance. Vol. 2. Città del Vaticano, Biblioteca Apostolica Vaticana, 1960. 497 p. (Studi e testi; 208).

9. Ducellier A. Chrétiens d'Orient et Islam au Moyen âge: VII $-X V^{e}$ siècle. Paris, A. Colin, 1996. 492 p.

10. Durak K. Defining the "Turk" : Mechanisms of Establishing Contemporary Meaning in the Archaizing Language of the Byzantines. Jahrbuch der Österreichischen Byzantinistik, 2009, vol. 59, pp. 65-78.

11. Laiou A. Byzantium and the Neighboring Powers: Small-State Policies and Complexities. Brooks S.T., ed. Byzantium: Faith and Power (12611557). Perspectives on Late Byzantine Art and Culture.
New Haven; London, Yale University Press, 2006, pp. 42-53.

12. Chrysostomides J., ed. Manuel II Palaeologus. Funeral Oration on His Brother Theodore. Thessalonike, Association for Byzantine Research, 1985.310 p.

13. Moravcsik G. Byzantinoturcica. II. Sprachreste der Türkvölker in den byzantinischen Quellen. Berlin, Akademie Verlag, 1958. xxv, 376 p.

14. Moustakas K. Byzantine "Visions" of the Ottoman Empire: Theories of Ottoman Legitimacy by Byzantine Scholars after the Fall of Constantinople. Lymberopoulou A., ed. Images of the Byzantine World: Visions, Messages and Meanings: Studies Presented to L. Brubaker. Farnham; Burlington, Ashgate Publ., 2011,pp. 215-229.

15. Necipoğlu N. Byzantium between the Ottomans and the Latins. Politics and Society in the Late Empire. Cambridge, Cambridge University Press, 2009. 350 p.

16. Obolensky D. The Principles and Methods of Byzantine Diplomacy. Actes du XII Congrès international d'études byzantines. Vol. 1. Beograd, Naučno delo, 1963, pp. 45-61.

17. Ostrogorsky G. Die byzantinische Staatenhierarchie. Seminarium Kondakovianum, 1936, vol. 8, pp. 41-61.

18. Preiser-Kapeller J.P. Conversion, Collaboration and Confrontation: Islam in the Register of the Patriarchate of Constantinople ( $14^{\text {th }}$ Century). International Review of Turkish Studies, 2011, vol. 1, iss. 4, pp. 62-79.

19. Radošević N. Waiting for the End-the Byzantine Rhetoric of the First Half of the Fifteenth Century. Zbornik radova Vizantološkog instituta [Recueil des travaux de l'Institut d'études byzantines], 2006, vol. 43, pp. 59-70.

20. Reinert S.W. Manuel II Palaeologos and His Müderris. Ćutčić S., Mouriki D., eds. The Twilight of Byzantium. Aspects of Cultural and Religious History in the Late Byzantine Empire. Princeton, Princeton University Press, 1991, pp. 39-51.

21. Reinert S.W. The Palaiologoi, Yildirim Bāyezīd and Constantinople: June 1389 - March 1391. Langdon J.S., Reinert S.W., Allen J., Ioannides Ch.,

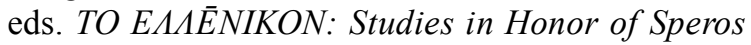
Vryonis. New Roshelle; New York, A.D. Caratzas, 1993, vol. 1, pp. 289-366.

22. Spiridonakis B.G. Grecs, Occidentaux et Turcs de 1054 à 1453: quatre siècles d'histoire de relations internationales. Thessaloniki, Institute for Balkan Studies, 1990. 291 p.

23. Strano G. Le rappresentazioni del nemico: Realien e ideologia nella trattatistica militare bizantina. Miscellanea di studi storici, 2009-2010, vol. 16, pp. 181-203. 


\section{СУДЬБА МАЛОЙ АЗИИ В ВОСПРИЯТИИ ВИЗАНТИЙЦЕВ}

24. Dennis G.T., ed. The Letters of Manuel II Palaeologus. Washington, Dumbarton Oaks Center for Byzantine Studies, 1977. $252 \mathrm{p}$.

25. Vryonis S. The Decline of Medieval Hellenism in Asia Minor and the Process of Islamization from the Eleventh through the Fifteenth Century. Berkeley; Los Angeles, California University Press, $1971.532 \mathrm{p}$.
26. Zachariadou E. Religious Dialogue between Byzantines and Turks during the Ottoman Expansion. Lewis B., Niewöhner F., eds. Religionsgespräche im Mittelalter. Wiesbaden, Otto Harrassowitz, 1992, pp. 289-304.

27. Zachariadou E. Manuel II Palaeologos on the Strife between Bayezid I and Kadi Burhan al-din Ahmad. Zachariadou E. Romania and the Turks (c. 1300-c. 1500). Vol. IV. London, Variorum Reprints, 1985, pp. 471-481.

\section{Information about the Author}

Tatiana V. Kushch, Doctor of Sciences (History), Associate Professor, Head of Department of Ancient and Medieval History, Ural Federal University, Prosp. Lenina, 51, 620000 Ekaterinburg, Russian Federation, tkushch@yandex.ru, https://orcid.org/0000-0001-9097-5466

\section{Информация об авторе}

Татьяна Викторовна Кущ, доктор исторических наук, доцент, заведующая кафедрой истории Древнего мира и Средних веков, Уральский федеральный университет, просп. Ленина, 51, 620000 г. Екатеринбург, Российская Федерация, tkushch@yandex.ru, https://orcid.org/0000-0001-9097-5466 